\title{
Front Matter: Volume 7376
}

, "Front Matter: Volume 7376," Proc. SPIE 7376, Laser Applications in Life Sciences, 737601 (17 December 2010); doi: 10.1117/12.886393

SPIE. Event: Laser Applications in Life Sciences 2010, 2010, Oulu, Finland 


\title{
PROCEEDINGS OF SPIE
}

\section{Laser Applications in Life Sciences}

\author{
Matti Kinnunen \\ Risto Myllylä \\ Editors
}

9-11 June 2010

Oulu, Finland

Organized by

Optoelectronics and Measurement Techniques Laboratory, University of Oulu (Finland) International Laser Centre of M.V. Lomonosov Moscow State University (Russian Federation)

VTT - Technical Research Centre of Finland (Finland)

Sponsored by

Biocenter Oulu (Finland)

University of Eastern Finland (Finland)

European Physical Society

Federation of Finnish Learned Societies (Finland)

Cooperating Organization and Publisher

SPIE

Volume 7376

Proceedings of SPIE, 0277-786X, v. 7376 
The papers included in this volume were part of the technical conference cited on the cover and title page. Papers were selected and subject to review by the editors and conference program committee. Some conference presentations may not be available for publication. The papers published in these proceedings reflect the work and thoughts of the authors and are published herein as submitted. The publisher is not responsible for the validity of the information or for any outcomes resulting from reliance thereon.

Please use the following format to cite material from this book:

Author(s), "Title of Paper," in Laser Applications in Life Sciences, edited by Matti Kinnunen, Risto Myllylä, Proceedings of SPIE Vol. 7376 (SPIE, Bellingham, WA, 2010) Article CID Number.

ISSN 0277-786X

ISBN 9780819476524

Published by

SPIE

P.O. Box 10, Bellingham, Washington 98227-0010 USA

Telephone +1 3606763290 (Pacific Time) · Fax +1 3606471445

SPIE.org

Copyright (c) 2010, Society of Photo-Optical Instrumentation Engineers

Copying of material in this book for internal or personal use, or for the internal or personal use of specific clients, beyond the fair use provisions granted by the U.S. Copyright Law is authorized by SPIE subject to payment of copying fees. The Transactional Reporting Service base fee for this volume is $\$ 18.00$ per article (or portion thereof), which should be paid directly to the Copyright Clearance Center (CCC), 222 Rosewood Drive, Danvers, MA 01923. Payment may also be made electronically through CCC Online at copyright.com. Other copying for republication, resale, advertising or promotion, or any form of systematic or multiple reproduction of any material in this book is prohibited except with permission in writing from the publisher. The CCC fee code is 0277-786X/10/\$18.00.

Printed in the United States of America.

Publication of record for individual papers is online in the SPIE Digital Library.

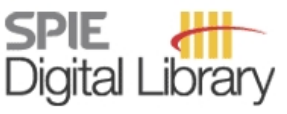

SPIEDigitalLibrary.org

Paper Numbering: Proceedings of SPIE follow an e-First publication model, with papers published first online and then in print and on CD-ROM. Papers are published as they are submitted and meet publication criteria. A unique, consistent, permanent citation identifier (CID) number is assigned to each article at the time of the first publication. Utilization of CIDs allows articles to be fully citable as soon they are published online, and connects the same identifier to all online, print, and electronic versions of the publication. SPIE uses a six-digit CID article numbering system in which:

- The first four digits correspond to the SPIE volume number.

- The last two digits indicate publication order within the volume using a Base 36 numbering system employing both numerals and letters. These two-number sets start with 00, 01, 02, 03, 04 , $05,06,07,08,09,0 A, 0 B \ldots$. OZ, followed by 10-1Z, 20-2Z, etc.

The CID number appears on each page of the manuscript. The complete citation is used on the first page, and an abbreviated version on subsequent pages. Numbers in the index correspond to the last two digits of the six-digit CID number. 


\section{Contents}

$\begin{array}{ll}\text { ix } & \text { Conference Committees } \\ \mathrm{XV} & \text { Introduction }\end{array}$

\section{SESSION 1 NANO-BIOPHOTONICS}

$737602 \quad$ Ripple-patterned substrates for light enhancement applications [7376-08]

R. Buividas, Swinburne Univ. of Technology (Australia); T. Kudrius, R. Šliupas, Vilnius Univ. (Lithuania) and Altechna Co. Ltd. (Lithuania); L. Rosa, Swinburne Univ. of Technology (Australia); G. Šlekys, Altechna Co. Ltd. (Lithuania); S. Bagdonas, R. Rotomskis, Vilnius Univ. (Lithuania); S. Juodkazis, Swinburne Univ. of Technology (Australia)

737603 CdTe quantum dots stabilization by protein in aqueous solution [7376-53] M. Matulionyte, D. Motekaitis, V. Poderys, R. Rotomskis, Vilnius Univ. (Lithuania)

737604 The development of SPR device for biomarker detection [7376-23]

P. Tervo, J. Katainen, A. Sesay, V. Virtanen, Univ. of Oulu (Finland)

737605 Development of diagnostic SPR based biosensor for the detection of pharmaceutical compounds in saliva [7376-22]

S. Sonny, A. M. Sesay, V. Virtanen, Univ. of Oulu (Finland)

737606 Laser-induced microbubbles in gold and oxide nanoparticle suspensions: photoacoustic detection [7376-44]

Z. Zhao, R. Myllylä, Univ. of Oulu (Finland)

737607 Complex of water-soluble CdSe/ZnS quantum dots and chlorin e6: interaction and FRET [7376-52]

J. Valanciunaite, A. Skripka, G. Streckyte, R. Rotomskis, Vilnius Univ. (Lithuania)

\section{SESSION 2 LASER-TISSUE INTERACTIONS}

737608 3D Monte Carlo model of optical transport in laser-irradiated cutaneous vascular malformations [7376-13]

B. Majaron, Jožef Stefan Institute (Slovenia) and Univ. of Ljubljana (Slovenia);

M. Milanič, Jožef Stefan Institute (Slovenia); W. Jia, J. S. Nelson, Univ. of California, Irvine (United States)

737609 Accelerated 3D Monte Carlo light dosimetry using a graphics processing unit (GPU) cluster [7376-54]

W. C. Y. Lo, Princess Margaret Hospital (Canada); L. Lilge, Princess Margaret Hospital (Canada) and Univ. of Toronto (Canada) 
7376 OA The photodynamic therapy effect of aluminum and zinc tetrasulfophthalocyanines on melanoma cancer cells [7376-10]

K. Maduray, Durban Univ. of Technology (South Africa) and Council for Scientific and Industrial Research (South Africa); A. Karsten, Council for Scientific and Industrial Research (South Africa); B. Odhav, Durban Univ. of Technology (South Africa); T. Nyokong, Rhodes Univ. (South Africa)

7376 OB IR spectroscopy vs. Raman scattering by measurement of glucose concentration [7376-48] O. Abdallah, Karlsruhe Institute of Technology (Germany); J. Hansmann, Univ. of Stuttgart (Germany); A. Bolz, Karlsruhe Institute of Technology (Germany); H. Mertsching, Univ. of Stuttgart (Germany)

7376 OC Composite fillings microleakage after TEMoo Er: YAG laser texturing of human tooth enamel surface [7376-37]

A. V. Belikov, K. V. Shatilova, A. V. Skrypnik, St. Petersburg State Univ. of Information Technologies, Mechanics and Optics (Russian Federation); D. Y. Fedotov, St. Petersburg Medical Academy of Postgraduate Studies (Russian Federation)

7376 OD Hard tooth tissue removal efficiency by single-mode low energy Er:YAG laser [7376-47] A. V. Belikov, A. V. Skrypnik, K. V. Shatilova, St. Petersburg State Univ. of Information Technologies, Mechanics and Optics (Russian Federation)

7376 OE Laser-induced skin temperature oscillations [7376-20] S. Podtaev, Perm State Univ. (Russian Federation); A. Dumler, N. Muravyov, Perm State Medical Academy named after E.A. Vagner (Russian Federation); M. Myasnikov, K. Tsiberkin, Perm State Univ. (Russian Federation)

7376 OF Skin phantoms with realistic vessel structure for OCT measurements [7376-57] A. V. Bykov, A. P. Popov, Univ. of Oulu (Finland) and Moscow State Univ. (Russian Federation); M. Kinnunen, T. Prykäri, Univ. of Oulu (Finland); A. V. Priezzhev, Moscow State Univ. (Russian Federation); R. Myllylä, Univ. of Oulu (Finland)

SESSION 3 LASER BIOMEDICAL DIAGNOSTICS, SENSING, AND THERAPY

7376 OG Interferometry for topographical diagnostics of RBCs in optical tweezers [7376-59]

R. Kumar, Indian Institute of Technology Delhi (India); S. Saraswati, Univ. of Delhi (India);

C. Shakher, D. S. Mehta, Indian Institute of Technology Delhi (India)

$7376 \mathrm{OH} \quad$ Polarization structure and spectral properties of aminoacid's crystal layers [7376-63]

S. B. Yermolenko, P. V. Ivashko, Chernivtsi National Univ. (Ukraine)

7376 Ol Spectropolarimetry features of biotissue's malignant changes [7376-64]

I. Gruia, Univ. of Bucharest (Romania); S. B. Yermolenko, Chernivtsi National Univ. (Ukraine);

C. Gavrila, Technical Univ. of Civil Engineering Bucharest (Romania); P. V. Ivashko, Chernivtsi National Univ. (Ukraine); M. I. Gruia, Institute of Oncology Bucharest (Romania)

$73760 \mathrm{~J}$ Multispectral imaging of pigmented and vascular cutaneous malformations: the influence of laser treatment [7376-58]

I. Kuzmina, I. Diebele, L. Asare, Univ. of Latvia (Latvia); A. Kempele, A. Abelite, The Clinic of Laserplastics (Latvia); D. Jakovels, J. Spigulis, Univ. of Latvia (Latvia) 
7376 OK Rapid flow cytometry analysis of antimicrobial properties of nettle powder and cranberry powder [7376-21]

M. Hattuniemi, J. Korhonen, M. Jaakkola, J. Räty, V. Virtanen, Univ. of Oulu (Finland)

$7376 \mathrm{OL} \quad$ Arterial stiffness estimation based photoplethysmographic pulse wave analysis [7376-46] M. Huotari, K. Määttä, J. Kostamovaara, Univ. of Oulu (Finland)

\section{SESSION 4 SINGLE CELLS AND MOLECULES; OPTICAL TRAPPING AND MANIPULATION}

$73760 \mathrm{M} \quad$ Microfluidic system for single cell sorting with optical tweezers [7376-39]

T. Bruns, Hochschule Aalen (Germany); L. Becsi, Hochschule Furtwangen (Germany); M. Talkenberg, M. Wagner, P. Weber, Hochschule Aalen (Germany); U. Mescheder, Hochschule Furtwangen (Germany); H. Schneckenburger, Hochschule Aalen (Germany)

\section{SESSION 5 THz WAVES IN BIOPHOTONICS}

7376 ON Electric oscillations generated by collective vibration modes of microtubule [7376-02] M. Cifra, Institute of Photonics and Electronics (Czech Republic) and Czech Technical Univ. in Prague (Czech Republic); D. Havelka, Czech Technical Univ. in Prague (Czech Republic); O. Kučera, Institute of Photonics and Electronics (Czech Republic) and Czech Technical Univ. in Prague (Czech Republic)

$737600 \quad$ Protein association investigated by THz spectroscopy and molecular modeling [7376-28] M. Mernea, O. Calborean, L. Petrescu, A. Tita, Univ. of Bucharest (Romania); A. Leca, T. Dascalu, National Institute for Laser, Plasma and Radiation Physics (Romania); D. F. Mihailescu, Univ. of Bucharest (Romania)

7376 OP Vibrational spectra of corticosteroid hormones in the terahertz range [7376-07] O. P. Cherkasova, Institute of Laser Physics (Russian Federation); M. M. Nazarov, D. A. Sapozhnikov, A. A. Man'kova, E. V. Fedulova, M.V. Lomonosov Moscow State Univ. (Russian Federation); V. A. Volodin, Institute of Semiconductor Physics (Russian Federation) and Novosibirsk State Univ. (Russian Federation); V. A. Minaeva, B. F. Minaev,

G. V. Baryshnikov, Bogdan Khmelnitskij National Univ. (Ukraine)

\section{SESSION 6 VIBRATIONAL SPECTROSCOPY, STRUCTURE, AND DYNAMICS OF BIOLOGICAL SYSTEMS}

$73760 Q \quad$ Sum frequency generation spectroscopy of amyloid fibrils and oligomers at air/water interface [7376-06]

G. Niaura, R. Budvytyte, Institute of Biochemistry (Lithuania); Z. Kuprionis, EKSPLA Ltd. (Lithuania); G. Valincius, Institute of Biochemistry (Lithuania)

7376 OR Electron detachment and recombination in aqueous solutions studied with 2- and 3-pulse femtosecond spectroscopy [7376-11]

H. Iglev, A. Laubereau, Technische Univ. München (Germany) 
7376 OS Improved signal extraction method for single-pulse heterodyne CARS spectroscopy [7376-29]

Y. Nagashima, The Univ. of Tokyo (Japan); T. Suzuki, Tokyo Univ. of Agriculture and Technology (Japan); S. Terada, Tokyo Medical and Dental Univ. (Japan); S. Tsuji, The Univ. of Tokyo (Japan); K. Misawa, Tokyo Univ. of Agriculture and Technology (Japan)

7376 OT Cancer tissue screening using surface enhanced Raman scattering [7376-32]

S. Cîntă Pînzaru, Babes-Bolyai Univ. (Romania); C. A. Dehelean, Victor Babeş Univ. of Medicine and Pharmacy (Romania); A. Fălămas, N. Leopold, C. Lehene, Babes-Bolyai Univ. (Romania)

7376 OU Surface plasmon dispersive spectroscopy of thin films at terahertz frequencies [7376-60] A. K. Nikitin, O. V. Khitrov, A. P. Kyrianov, Scientific and Technological Ctr. for Unique Instrumentation (Russian Federation); B. A. Knyazev, Budker Institute of Nuclear Physics (Russian Federation) and Novosibirsk State Univ. (Russian Federation); G. N. Zhizhin, Scientific Technological Ctr. of Unique Instruments (Russian Federation)

7376 OV Biophysical studies on the structure and function of molecules from the vertebrate myelin sheath [7376-26]

C. Wang, M. Myllykoski, Univ. of Oulu (Finland); P. Kursula, Univ. of Oulu (Finland) and German Electron Synchrotron (Germany)

\section{SESSION 7 MOLECULAR AND BIO-IMAGING}

7376 OW New staining methods for yeast like fungi under special consideration of human pathogenic fungi [7376-12]

A. Paulitsch-Fuchs, Wetsus, Ctr. of Excellence for Sustainable Water Technology (Netherlands) and Medical Univ. of Graz (Austria); F. Treiber, E. Grasser, W. Buzina, Medical Univ. of Graz (Austria); C. Rosker, Univ. of Bern (Switzerland)

7376 0X Infrared absorbing dyes tailored for detection and therapy of solid tumors [7376-42]

F. A. Schaberle, L. G. Arnaut, C. Serpa, E. F. F. Silva, M. M. Pereira, A. R. Abreu, S. Simões, Univ. of Coimbra (Portugal)

7376 OY Development of a novel stigmatic imaging mass spectrometer using laser ionization and a multi-turn time-of-flight mass spectrometer [7376-30]

K. Awazu, H. Hazama, H. Yoshimura, J. Aoki, H. Nagao, M. Toyoda, Osaka Univ. (Japan) and JST, CREST (Japan); K. Masuda, Suntory Institute for Bioorganic Research (Japan) and JST, CREST (Japan); K. Fujii, Osaka Institute of Technology (Japan) and JST, CREST (Japan); T. Tashima, JST, CREST (Japan); Y. Naito, The Graduate School for the Creation of New Photonics Industries (Japan) and JST, CREST (Japan)

$73760 Z$ Widefield TSCSPC-systems with large-area-detectors: application in simultaneous multi-channel-FLIM [7376-51]

S. Stepanov, S. Bakhlanov, E. Drobchenko, Petersburg Nuclear Physics Institute (Russian Federation); H.-J. Eckert, Technische Univ. Berlin (Germany); K. Kemnitz, EuroPhoton GmbH (Germany)

737610 A wide-field multi-parameter FLIM and FRAP setup to investigate the fluorescence emission of individual living cyanobacteria [7376-49]

M. Vitali, M. Reis, T. Friedrich, H.-J. Eckert, Technische Univ. Berlin (Germany) 
737611 FRET-sensor for imaging with lifetime resolution [7376-31]

A. L. Rusanov, M.V. Lomonosov Moscow State Univ. (Russian Federation) and A.N. Bach Institute of Biochemistry (Russian Federation); T. V. Ivashina, Skryabin Institute of Biochemistry and Physiology (Russian Federation); L. M. Vinokurov, Shemyakin and Ovchinnikov Institute of Bioorganic Chemistry (Russian Federation); A. S. Goryashenko, M.V. Lomonosov Moscow State Univ. (Russian Federation) and A.N. Bach Institute of Biochemistry (Russian Federation); V. V. Zherdeva, A.N. Bach Institute of Biochemistry (Russian Federation); A. P. Savitsky, M.V. Lomonosov Moscow State Univ. (Russian Federation) and A.N. Bach Institute of Biochemistry (Russian Federation)

737612 Time-resolved 3D confocal fluorescence microscopy on living cells [7376-43] M. Schellenberg, E. Peev, M. Kloster, J. Napier, W. Neu, Univ. of Applied Sciences Emden/Leer (Germany)

737613 Diffraction tomography for biological cells imaging using digital holographic microscopy [7376-15]

I. Bergoënd, C. Arfire, N. Pavillon, C. Depeursinge, Ecole Polytechnique Fédérale de Lausanne (Switzerland)

737614 In-line color digital holographic microscope for water quality measurements [7376-17] Z. Göröcs, L. Orzó, M. Kiss, V. Tóth, S. Tőkés, Computer and Automation Research Institute (Hungary)

737615 Using digital holographic microscopy for 4D tracking of colloid particles [7376-38] D. Ekimov, Petrozavodsk State Univ. (Russian Federation); V. Kaikkonen, A. Mäkynen, Univ. of Oulu (Finland)

\section{SESSION 9 NOVEL OPTICAL DEVICES FOR BIOMEDICINE}

737616 Yellow-red semiconductor disk lasers for biophotonics applications [7376-14] T. Leinonen, A. Härkönen, V.-M. Korpijärvi, J. Puustinen, M. Guina, Tampere Univ. of Technology (Finland)

737617 Evaluation of microfluidic channels with optical coherence tomography [7376-34] J. Czajkowski, T. Prykäri, Univ. of Oulu (Finland); E. Alarousu, King Abdullah Univ. of Science and Technology (Saudi Arabia); J. Lauri, R. Myllylä, Univ. of Oulu (Finland)

737618 RGB imaging of laser-excited skin autofluorescence bleaching rates [7376-41] D. Jakovels, J. Spigulis, Univ. of Latvia (Latvia)

737619 Measurement of light scattering from trapped particles [7376-55] M. Collins, A. Kauppila, Univ. of Oulu (Finland); A. Karmenyan, National Yang-Ming Univ. (Taiwan); L. Gajewski, K. Szewczyk, Silesian Univ. of Technology in Gliwice (Poland); M. Kinnunen, R. Myllylä, Univ. of Oulu (Finland) 
7376 1A Fabrication of polymer waveguide devices for sensor applications [7376-24]

M. Cheng, Univ. of Oulu (Finland); J. Hiltunen, VTT, Technical Research Ctr. of Finland

(Finland); M. Wang, A. Suutala, Univ. of Oulu (Finland); P. Karioja, VTT, Technical Research

Ctr. of Finland (Finland); R. Myllylä, Univ. of Oulu (Finland)

\section{SESSION 11 SYMPOSIUM ON WATER IN BIOENVIRONMENT: SPECTROSCOPY AND SIMULATION}

7376 1B Hydrogen bonding in aqueous ethanol solutions studied by Raman spectroscopy [7376-18]

T. Dolenko, S. Burikov, Moscow State Univ. (Russian Federation); M. Hojo, Kochi Univ. (Japan);

S. Patsaeva, V. Yuzhakov, Moscow State Univ. (Russian Federation)

7376 1C Long-range attraction in aqueous colloidal suspensions [7376-56]

Q. Zhao, Univ. of Washington (United States) and Peking Univ. (China); J. Coult, G. H. Pollack, Univ. of Washington (United States)

7376 1D Laser scattering in water and aqueous solutions of salts [7376-25]

N. F. Bunkin, A. V. Shkirin, Prokhorov General Physics Institute (Russian Federation);

V. A. Kozlov, Bauman Moscow State Technical Univ. (Russian Federation); A. V. Starosvetskiy, Moscow Engineering Physics Institute (Russian Federation)

7376 IE Mass and charge transfer within a floating water bridge [7376-01]

E. C. Fuchs, L. L. F. Agostinho, Wetsus, Ctr. of Excellence for Sustainable Water Technology (Netherlands); M. Eisenhut, Wetsus, Ctr. of Excellence for Sustainable Water Technology (Netherlands) and Graz Univ. of Technology (Austria); J. Woisetschläger, Graz Univ. of Technology (Austria)

7376 IF Spectroscopy on laser induced plasma in cavitation bubbles [7376-45]

S. Koch, Univ. of Applied Sciences Emden/Leer (Germany); M. Reck, Carl von Ossietzky Univ. Oldenburg (Germany); W. Neu, Univ. of Applied Sciences Emden/Leer (Germany);

R. Reuter, Carl von Ossietzky Univ. Oldenburg (Germany)

Author Index 


\title{
Conference Committees
}

\author{
Conference Chair
}

Risto Myllylä, University of Oulu (Finland)

\author{
Program Committee Chair \\ Victor Zadkov, M.V. Lomonosov Moscow State University (Russian \\ Federation)
}

Program Committee Cochairs

1 Nano-Biophotonics

Andrey Zvyagin, Macquarie University (Australia)

Ricardas Rotomskis, Vilnius University (Lithuania)

2 Laser-Tissue Interactions

Valery Tuchin, Saratov State University (Russian Federation)

Stefan Andersson-Engels, Lund University (Sweden)

3 Laser Biomedical Diagnostics, Sensing, and Therapy

Alexander Priezzhev, Moscow State University (Russian Federation) Janis Spigulis, University of Latvia (Latvia)

$4 \quad$ Single Cells and Molecules; Optical Trapping and Manipulation

Arthur Chiou, National Yang-Ming University (Taiwan)

Karl Otto Greulich, Leibniz Institute for Age Research (Germany)

$5 \quad$ THz Waves in Biophotonics

Alexander Shkurinov, Moscow State University (Russian Federation)

Xi-Cheng Zhang, Rensselaer Polytechnic Institute (United States)

6 Vibrational Spectroscopy, Structure, and Dynamics of Biological Systems

Maxim Pshenichnikov, University of Groningen (Netherlands)

Hiro-o Hamaguchi, University of Tokyo (Japan)

$7 \quad$ Molecular and Bio-Imaging

Alexander Savitsky, A.N. Bach Institute of Biochemistry of Russian Academy of Sciences (Russian Federation)

Nikolaos Deliolanis, Institute for Biological and Medical Imaging (Germany) 
Jiri Homola, Institute of Photonics and Electronics (Czech Republic)

Pekka Hänninen, University of Turku (Finland)

9 Novel Optical Devices for Biomedicine

Victor Loshchenov, General Physics Institute of the Russian Academy of Sciences (Russian Federation)

Timo Jääskeläinen, University of Eastern Finland (Finland)

10 Printing Techniques and their Applications in Biotechnology

Ghassan Jabbour, King Abdullah University of Science and Technology (Saudi Arabia) and University of Oulu (Finland)

11 Symposium on Water in Bioenvironment: Spectroscopy and Simulation Gerald Pollack, University of Washington (United States)

\section{Organizing Committee Chair}

Matti Kinnunen, University of Oulu (Finland)

Local Organizing Committee

Päivi Ronkainen, University of Oulu (Finland)

Alexey Popov, University of Oulu (Finland)

Alexander Bykov, University of Oulu (Finland)

Eija Vieri-Gashi, University of Oulu (Finland)

Meng Wang, University of Oulu (Finland)

Jakub Czajkowski, University of Oulu (Finland)

Tapio Fabritius, University of Oulu (Finland)

Zuomin Zhao, University of Oulu (Finland)

Jukka Hast, VTT, Oulu (Finland)

Seppo Vainio, Biocenter Oulu (Finland)

Aki Manninen, Biocenter Oulu (Finland)

International Advisory Board

Victor Zadkov, Chair, M.V. Lomonosov Moscow State University (Russian Federation)

Rafat Ansari, NASA Glenn Research Center (United States)

Sanford Asher, University of Pittsburgh (United States)

Andrey Chikishev, M.V. Lomonosov Moscow State University (Russian Federation)

Arthur Chiou, National Yang-Ming University (Taiwan)

Dusan Chorvat, International Laser Center (Slovakia)

Benjamin Chu, State University of New York (United States)

Karl-Heinz Feller, University of Applied Sciences Jena (Germany)

Karl-Otto Greulich, Leibniz Institute for Age Research (Germany) 
Hiro-o Hamaguchi, The University of Tokyo (Japan)

Alfons Hoekstra, University of Amsterdam (Netherlands)

Jouko Korppi-Tommola, University of Jyväskylä (Finland)

Alfred Laubereau, Technische Universität München (Germany)

Qingming Luo, Huazhong University of Science and Technology

(China)

Risto Myllylä, University of Oulu (Finland)

Valentin Orlovich, National Academy of Sciences of Belarus (Belarus)

Cees Otto, University of Twente (Netherlands)

Alexander Priezzhev, M.V. Lomonosov Moscow State University

(Russian Federation)

Leonard Proniewicz, Jagiellonian University (Poland)

Ricardas Rotomskis, Vilnius University (Lithuania)

Hiroaki Takahashi, Waseda University (Japan)

George Thomas, The State University of New Jersey (United States)

Valery Tuchin, Saratov State University (Russian Federation)

Christian von Borczyskowski, Technische Universität Chemnitz

(Germany)

\section{Session Chairs}

Plenary Lectures

Risto Myllylä, University of Oulu (Finland)

Victor Zadkov, M.V. Lomonosov Moscow State University (Russian

Federation)

Alexander Priezzhev, M.V. Lomonosov Moscow State University

(Russian Federation)

Nano-Biophotonics I

Ricardas Rotomskis, Vilnius University (Lithuania)

Nano-Biophotonics II

Sergey Deyev, Russian Academy of Sciences (Russian Federation)

Nano-Biophotonics III

Andrei Zvyagin, Macquarie University (Australia)

Single Cells and Molecules I: Instrumentation

Karl Otto Greulich, Leibniz Institute for Age Research (Germany)

Single Cells and Molecules II: From Instrumentation to Applications Josef Käs, Universität Leipzig (Germany)

Single Cells and Molecules III: Applications

Arthur Chiou, National Yang-Ming University (Taiwan) 
Novel Optical Devices for Biomedicine I

Arthur Chiou, National Yang-Ming University (Taiwan)

Novel Optical Devices for Biomedicine II

Barry Cense, Utsunomiya University (Japan)

Novel Optical Devices for Biomedicine III

Rudolf Steiner, Universität Ulm (Germany)

Laser Microscopies I

Timo Jääskeläinen, University of Eastern Finland (Finland)

Laser Microscopies II

Victor Loshchenov, General Physics Institute of the Russian Academy of Sciences (Russian Federation)

Laser Microscopies III

Timo Zimmermann, Centre for Genomic Regulation (Spain)

THz Waves in Biophotonics I

Alexander Shkurinov, Moscow State University (Russian Federation)

THz Waves in Biophotonics II

Kodo Kawase, Nagoya University (Japan)

THz Waves in Biophotonics III

Martina Havenith, Ruhr-Universität Bochum (Germany)

THz Waves in Biophotonics IV

Ingrid Wilke, Rensselaer Polytechnic Institute (United States)

Laser-Tissue Interactions I

Valery Tuchin, Saratov State University (Russian Federation)

Laser-Tissue Interactions II

Francesco Pavone, Università degli Studi di Firenze (Italy)

Laser-Tissue Interactions III

Steven Jacques, Oregon Health and Science University (United States)

Laser-Tissue Interactions IV

Horacio Lamela, Universidad Carlos III de Madrid (Spain)

Molecular and Bio-Imaging I

Frank Chuang, University of California, Davis (United States) 
Molecular and Bio-Imaging II

Nikolaos Deliolanis, Institute for Biological and Medical Imaging (Germany)

Molecular and Bio-Imaging III

Alexander Savitsky, A.N. Bach Institute of Biochemistry of the Russian Academy of Sciences (Russian Federation)

Molecular and Bio-Imaging IV

Giannis Zacharikis, Institute of Electronic Structure and Laser FORTH-IESL (Greece)

Symposium on Water in Bioenvironment I

Gerald Pollack, University of Washington (United States)

Symposium on Water in Bioenvironment II

Elmar Fuchs, Wetsus - Centre of Excellence for Sustainable Water Technology (Netherlands)

Symposium on Water in Bioenvironment III

Thomas Jansen, University of Groningen (Netherlands)

Symposium on Water in Bioenvironment IV

Sergey Pershin, Prokhorov General Physics Institute (Russian Federation)

Laser Biomedical Diagnostics, Sensing, and Therapy I

Alexander Priezzhev, M.V. Lomonosov Moscow State University (Russian Federation)

Laser Biomedical Diagnostics, Sensing, and Therapy II

Irving Bigio, Medicine Boston University (United States)

Laser Biomedical Diagnostics, Sensing, and Therapy III

Jürgen Lademann, Charité - Universitätsmedizin Berlin (Germany)

Laser Biomedical Diagnostics, Sensing, and Therapy IV

Rafat Ansari, NASA Glenn Research Center (United States)

Laser-Tissue Interactions $\mathrm{V}$

Victor Loshchenov, General Physics Institute of the Russian Academy of Sciences (Russian Federation)

Laser-Tissue Interactions $\mathrm{VI}$

Alexander Krasnovsky, A.N. Bach Institute of Biochemistry (Russian Federation) 
Laser-Tissue Interactions VII

Elena Zagaynova, Nizhny Novgorod State Medical Academy (Russian Federation)

Vibrational Spectroscopy, Structure, and Dynamics of Biological Systems I

Maxim Pshenichnikov, University of Groningen (Netherlands)

Vibrational Spectroscopy, Structure, and Dynamics of Biological Systems II

Andrei Chikishev, M.V. Lomonosov Moscow State University (Russian Federation)

Vibrational Spectroscopy, Structure, and Dynamics of Biological Systems III

Jouko Korppi-Tommola, University of Jyväskylä (Finland)

Vibrational Spectroscopy, Structure, and Dynamics of Biological Systems IV

Hiroaki Takahashi, Waseda University (Japan)

Symposium on Bioprinting I

Hanna Haverinen, University of Oulu (Finland) 


\section{Introduction}

Laser Applications in Life Sciences (LALS-2010) was held in Oulu, Finland, 9-11 June 2010. This conference belongs to a series of biannual conferences starting in the year 1986. The conference was jointly organized by Optoelectronics and Measurement Techniques Laboratory of the University of Oulu (Finland), International Laser Center of M.V. Lomonosov Moscow State University (Russia), and VTT - Technical Research Centre of Finland.

The LALS conference brings together scientists from east and west working on the frontiers of laser physics, spectroscopy, biophysics, and biochemistry, who share common interests in the given areas. The key topics of LALS-2010 were NanoBiophotonics, Laser-Tissue Interactions, Laser Biomedical Diagnostics, Sensing, and Therapy, Single Cells and Molecules; Optical Trapping and Manipulation, $\mathrm{THz}$ Waves in Biophotonics, Vibrational Spectroscopy of Biological Systems, Molecular and Bio-Imaging, Laser Microscopies, and Novel Optical Devices for Biomedicine. In addition, two new topics were included in the LALS-2010 conference, namely, Printing Techniques and Their Applications in Biotechnology, and Symposium on Water in Bioenvironment: Spectroscopy and Simulation.

The conference was a great success. People from all continents contributed to the program. The largest number of participants in the history of the LALS conference series substantiates the necessity of continuing the series in the future. The papers presented at the conference and in this proceedings volume provide an excellent glimpse of the future and the current state of the art of this rapidly growing technology area.

\section{Matti Kinnunen Risto Myllylä}


Downloaded From: https://www.spiedigitallibrary.org/conference-proceedings-of-spie on 26 Apr 2023

Terms of Use: https://www.spiedigitallibrary.org/terms-of-use 